\title{
A Theory for Industrial Make-Buy Decisions?
}

\section{R Snaddon}

School of Mechanical Engineering, University of the Witwatersrand

\section{R Probert}

Department of Engineering, Cambridge University

\begin{abstract}
After an introduction, the authors derive some common industrial make-buy situations. Six prominent economic theories of the firm are then outlined, before setting criteria to select the most appropriate economic theory for deciding when to make and when to buy. An augmented transactions cost theory may well be the most secure basis for a manager, in an industrial setting, to decide what to make within, and what to buy outside, the firm.
\end{abstract}

JEL D23

\section{INTRODUCTION}

Managers often decide whether to make or buy a part or process. They can use rules of thumb such as installing parts that

- $\quad$ are cheaper to make than buy,

- are new,

- $\quad$ are within the competence of the firm, or

- avoid problems dealing with sellers.

Consider the rule to make new parts and processes. When a part has never been made before it may be easier ${ }^{1}$ to make it than to describe it for someone else to make. Similar situations can be constructed for the other rules leading to the conclusion that all these rules of thumb may be credible in different situations. While credible, these rules may contradict each other. For example in a particular situation it may be cheaper to buy a new part meaning that the first two rules cannot be met simultaneously.

This implies some fundamental theories from which approaches and rules arise. Such a theory can provide a basis to help the manager to answer the question should this part or process be sourced in-house or bought from a supplier? ${ }^{2}$ The process of finding the theory consists of 
- describing the situation,

- outlining the fundamental make-buy theories,

- $\quad$ setting criteria for selection, and then

- making a selection.

\section{DERIVATION OF SITUATION}

Managers within competitive industry take make-buy decisions involving conventional parts and processes. The make-buy decisions considered are resolutions taken over the longer term involving investments in capital, labour and processes. Such decisions include raw materials and parts procurement as well as production processes. Trivial purchases are excluded, as are unconventional transactions. Conventional parts and processes are restricted to those that

- allow the decision to change after locating the plant (e.g. we exclude situations like buying coal for coal-fired electrical generating plants, etc.);

- exclude ulterior motives like taking over the supplier;

- occur frequently (unlike large capital items purchased as "one-offs", e.g. a dam); and

- are not epochal changes in technology (like changing from electronic valves to transistors).

Restrictions are not onerous and allow for many industrial make-buy decisions. Examples include financial and other information technologies, product development, scrap disposal, and utility supplies. To this must be added all components and raw materials for manufacturing.

Managers, taking conventional make-buy decisions, focus on particular factors they regard as important. If managers act in the interests of the firm, such factors indicate importance and help to distinguish between theories. To determine important factors in make-buy decisions two sources are used below. First, secondary data were drawn from articles by practitioners. Second, data from a previously unpublished survey of South African pump and valve manufacturing managers are reported.

Table 1 Practitioners" Factors for Making and Buying

\begin{tabular}{|l|c|}
\hline \multicolumn{1}{|c|}{ Buy-; Make-; Make or Buy Decision Factors } & Total Frequency \\
\hline (A) Cost or price & 6 \\
\hline (B) Other factors not specified elsewhere & 6 \\
\hline (C) Volume or demand & 4 \\
\hline
\end{tabular}


Table 1 continued

\begin{tabular}{|l|c|}
\hline \multicolumn{1}{|c|}{ Buy-; Make-; Make or Buy Decision Factors } & Total Frequency \\
\hline (D) Speed & 4 \\
\hline (E) Competence, strategy or strategic & 3 \\
\hline (F) Inadequate resources & 3 \\
\hline (G) Trust, security and theft & 2 \\
\hline
\end{tabular}

A limited set of practitioners' articles were read and words associated with subcontracting, outsourcing or buying on the one hand or making on the other hand were captured. Words were then transferred and counted (see Appendix 1). Table 1 is a summary of these results. In this figure "cost" is most frequent with "volume" and "speed" second, etc. ("Other factors" is a general category.)

To augment these views, a previously unpublished market research of South African pump- and valve-manufacturing managers' reasons for subcontracting, where one of the authors was involved, are disclosed. Views are analysed from the open-ended question, "For what reason does your business use subcontractors for any part of the production process (including) product and process development?" (Newell, 1996: 99). Table 2 shows the results given by forty-five managers (Newell, 1996: 78).

Table 2 Reasons for buying (subcontracting) for SA pump and valve manufacturers

\begin{tabular}{|l|c|c|l|c|c|}
\hline $\begin{array}{l}\text { Response } \\
\text { Category }\end{array}$ & $\begin{array}{l}\text { No of Re- } \\
\text { sponses }\end{array}$ & $\begin{array}{l}\text { Ranking of } \\
\text { Responses }\end{array}$ & $\begin{array}{l}\text { Response } \\
\text { Category }\end{array}$ & $\begin{array}{l}\text { No of Re- } \\
\text { sponses }\end{array}$ & $\begin{array}{l}\text { Ranking of } \\
\text { Responses }\end{array}$ \\
\hline $\begin{array}{l}\text { Skill, } \\
\text { facilities } \\
\text { and capital } \\
\text { (expenditure } \\
\text { avoidance) }\end{array}$ & 49 & 1 & $\begin{array}{l}\text { Non-core, } \\
\text { focus }\end{array}$ & 3 & 7 \\
\hline Demand & 23 & 2 & Routing & 2 & 8 \\
\hline $\begin{array}{l}\text { Cost } \\
\text { minimising }\end{array}$ & 11 & 3 & $\begin{array}{l}\text { Competi- } \\
\text { tiveness }\end{array}$ & 1 & \\
\hline $\begin{array}{l}\text { Labour } \\
\text { manage- } \\
\text { ment }\end{array}$ & 6 & 4 & $\begin{array}{l}\text { Knowledge of } \\
\text { market } \\
\text { pricing }\end{array}$ & 1 & \\
\hline Breakdown & 4 & 5 & Trend & 1 & \\
\hline Delivery & 4 & 5 & Product range & 1 & \\
\hline Quality & 3 & 7 & Total & 111 & \\
\hline
\end{tabular}


The three most frequent subcontracting reasons in Table 2 account for threequarters of the responses for subcontracting. These reasons are "skill, facilities and capital", "demand" and "cost minimising". The first category "skill, facilities and capital" refers to situations where resources are not available at the time when the subcontracting decision is made, but after the work has been accepted. It may be that the machines cannot make to the required tolerances, and this is thus a short-term decision in the economic sense. "Demand" refers to circumstances where demand exceeds a resource constraint, for example, not enough machining capacity, not enough labour. In other cases this refers to work that disturbs high volume production. (One response refers to such work as "nuisance work".) "Demand" refers to those responses that attempt to allow the firm to operate within a given capacity range. It is a physical measure of volume. Compare results in Table 2 and Table 1. In Table 2 "skill, facilities and capital" indicate "inadequate resources" for making. "Demand" in Table 2 is a "volume" effect similar to that in Table 1. Similarly, practitioners advocating "cost minimising" in Table 2, see "cost" as an important factor in Table 1. When sources are combined from tables 1 and 2 , then the top replicated factors, in order of combined rank for making and buying, are shown in Table 3. The order is "cost", then "inadequate resources" and "volume" (or demand). Core tasks or strategy may also be important. Many other factors could also make a difference.

Table 3 Practitioners' Factors in Make-Buy Decisions by Combined Rank

\begin{tabular}{|l|c|l|c|c|}
\hline $\begin{array}{l}\text { Category in } \\
\text { Table 1 }\end{array}$ & $\begin{array}{l}\text { Literature } \\
\text { Ranking }\end{array}$ & $\begin{array}{l}\text { Category in } \\
\text { Table 2 }\end{array}$ & $\begin{array}{l}\text { Market } \\
\text { research } \\
\text { ranking }\end{array}$ & $\begin{array}{l}\text { Combined } \\
\text { Rank }\end{array}$ \\
\hline Column 1 & Column 2 & Column 3 & Column 4 & Col, 2 + Col. 4 \\
\hline Cost & 1 & Cost minimising & 3 & 4 \\
\hline Volume & 3 & Demand & 2 & 5 \\
\hline $\begin{array}{l}\text { Inadequate } \\
\text { resources }\end{array}$ & 5 & Skill, facilities & 1 & 6 \\
\hline $\begin{array}{l}\text { Speed, rapid, } \\
\text { fast, save time }\end{array}$ & 3 & Delivery & 5 & 8 \\
\hline Strategic, core & 5 & Non-core, focus & 7 & 12 \\
\hline Reliability & 8 & Breakdown & 5 & 13 \\
\hline
\end{tabular}

Both combining ranks and the representative nature of the market research for all conventional industrial situations may be queried. Combined ranks in Table 3 (that are renumbered in Table 4) are therefore indicative rather than highly accurate. 


\section{Table 4 Ranking of Important Factors in Make-Buy Decisions by Practitioners}

\begin{tabular}{|l|c|}
\hline Factors & Rank \\
\hline Cost or Cost minimising & 1 \\
\hline Volume or Demand & 2 \\
\hline Inadequate resources or Skill, facilities & 3 \\
\hline Speed, rapid, fast, save time or Delivery & 4 \\
\hline Strategic, core or Non-core, focus & 5 \\
\hline Reliability or Breakdown & 6 \\
\hline
\end{tabular}

Managers, in competitive manufacturing, making make-buy decisions involving conventional parts and processes, seem to rank cost as most important, followed by volume considerations. Other important factors include inadequate resources and speed.

\section{ECONOMIC THEORIES FOR MAKE-BUY}

Various theories for make-buy decisions are found in the supply chain, purchasing, marketing and strategic management literature. Managers take decisions in firms and firms exist to produce and sell goods and services. If managers decide to make, then their firm makes. If managers decide to buy, then another firm makes. Managers faced with the make-buy decision, therefore decide who makes. If managers always decide to make, then their firm grows to make all parts and processes. It vertically integrates expanding towards mining raw materials and retailing to customers. If managers always decide to buy, the firm contracts until all parts and processes are bought from other firms. The final stage is buying (or subcontracting) the managers' work. After this the firm ceases to be a productive system, economically changing inputs into outputs. So the economic reason for a firm ceases. The size and existence of the firm depend upon make-buy decisions. So the reasons for the firm and make-buy decisions are closely intertwined. Theories of the firm are therefore likely to be closely related to make-buy theories. A starting point for economic make-buy decisions is then the economic theories of the firm.

The manager deciding whether to make or buy, using economic theories of the firm, still has a wide choice. As Machlup (1967: 26) says, "I am sure that there are at least 21 concepts of the firm employed in the literature of business and economics." Restricting the choice to longer-term make-buy choices, corresponds to limiting economic theories of the firm to those with a strategic 
management orientation. We follow Conner's (1991) classification of six approaches which focuses on strategic management ${ }^{3}$, namely

- Neo-classical,

- Bain-type industrial organisation,

- Schumpeter,

- Chicago,

- Coase-Williamson, and

- Resource-based theory ${ }^{4}$.

\section{CRITERLA FOR SELECTING A THEORY}

A theory chosen for the make-buy decision must allow the question of make or buy to be asked and answered, lead to patent factors, and should accord with factors cited by practitioners as important. The theory:

- must allow the question of make or buy to be asked and answered We link the make-buy decision to theories of firms. Hence each theory presented should allow the make-buy decision to be asked and answered. If the theory does not allow the decision to be made, then either the theory should be rejected or expanded to include the make-buy decision. Theories can be judged by the questions that can be asked and answered by means of them (Loasby, 1976: 212).

\section{- must lead to patent factors}

When investigating theories, care must be exercised. While theorists point to specific factors, they assume that other factors will remain the same (the ceteris paribus condition). As such, each theory is useful for factors patently noted in the theory. (Empiricists trying to validate one theory, often include factors that may be construed as giving credence to another theory, and so we limit the discussion to patent factors and not ceteris paribus conditions).

- should accord with factors cited by practitioners as important

A theory should be congruent with the situation described including some factors in Table 4. 


\section{SELECTION OF A THEORY FOR THE GIVEN SITUATION AND EXPLANATION OF THE SELECTED THEORY}

We follow Conner's (1991) classification but combine neo-classical competition theory with the Chicago tradition, and discuss the Coase-Williamson approach after Resource-based theory.

- Neo-classical and Chicago approach to make-buy

Conner (1991) only deals with neo-classical perfect competition theory. This theory allows managers to combine inputs making outputs. The firm buys inputs that it combines and makes into an end product. We remove some of the restrictive conditions of perfect competition (e.g. that each firm exactly replicates other competing firms that survive) and allow managers in the firm some latitude in determining make-buy decisions which, in turn, may imply some monopoly power.

- must allow the question of make or buy to be asked and answered, Neo-classical competition analysis sees managers in firms combining inputs, and deciding what to make and buy, especially if the firm is either a monopolist or monopsonist. As the firm becomes more competitive, decisions become prescribed. The Chicago school (especially Stigler) extends neo-classical analysis to distribution efficiencies in the supply chain. The neo-classical and Chicago approaches to the firm lead to comparing the costs of making and buying. These theories give rise to models like break-even analysis, ABC costing, etc., which allow the make-buy question to be asked and answered.

- must lead to patent factors, and

These theories patently consider:

- cost differences and

- volume effects

- $\quad$ should accord with factors cited by practitioners as important.

Cost differences and volume effects are the first two factors in Table 4.

This theory is acceptable and forms a standard which other theories can improve

- Bain

Bain's emphasis is that managers restrain market outputs, doing this collusively with managers in other firms. Managers raise and lower barriers to those wishing to enter and leave the industry. This leads to the structure-conductperformance (SCP) model (e.g. Hay and Morris, 1991, Part 2). 
- must allow the question of make or buy to be asked and answered

Bain's approach identifies useful elements and linkages that operate in industry in the SCP model. Analyses consider make-buy decisions at industry level measuring the concentration of firms supplying to, or demanding from, markets. Such theory is useful for buying and selling firms (mergers and takeovers).

\section{- $\quad$ must lead to patent factors, and}

There are many patent factors in this model. They include the

- number of buyers and sellers in the market;

- barriers to entry such as differentiating the product directly or through advertising;

- degree of spare capacity available; and

- vertical integration practised.

These factors can influence the make-buy decision. The number of buyers and sellers in a market point to the degree of monopoly there, which has already received comment. Product differentiation can be accomplished by making or buying extra enhancement and promotion. A firm's spare capacity can be used to change volume quickly (by changing the make-buy decision), and increased vertical integration increases the length of the supply chain on which make-buy decisions can be made.

\section{- $\quad$ should accord with factors cited by practitioners as important}

While the approach is general, complexity of the SCP model makes it difficult to test and also makes predictions weak. (See e.g. Peltzman's review (199l, especially p.213)). In addition, it focuses mainly upon industry rather than specific firms. A proponent of the SCP model, Porter, asks how much the specific industry matters in determining profitability, as opposed to other variables. He estimates that industry type accounts for $19 \%$ of profit variation, while business-specific matters account for $32 \%$, and $43 \%$ is unexplained (McGahan and Porter, 1997). This indicates that less than a fifth of profitability is explained by this rather general approach. If this is true for the theory of the firm, we do not see that it could explain more in the case of the make-buy decision.

Consider the patent factors above and those in Figure 4. Spare capacity may explain the interest in speed, but note that that this is rather speed by any producer rather than speed by the manager making the decision. The factors do not highlight the contents of the figure directly. The SCP model rather finds application in buying and selling firms (mergers and takeovers). Such activity is regarded as an ulterior motive, that is unlikely to happen often for the situation under consideration. 
As the SCP model is overly complex and has weak predictive power for the manager in the given situation, it is excluded here

\section{- Schumpeter}

This approach links the firm to innovation. The firm tries to innovate making rival products obsolete and is based upon the notion of "creative destruction".

- must allow the question of make or buy to be asked and answered, Schumpeter's theory of creative destruction deals with epochchanging products where making and buying are subsidiary to innovating. Consider innovating relative to the factors in Table 4. A link exists between innovating and provision for inadequate resources, enhancing the core of the business, or services like speed or reliability. However, when seen in terms of prosaic make-buy decisions, the link is of a longer term than that faced by the manager.

- $\quad$ must lead to patent factors, and

The patent factor is innovation which is not in Table 4.

- $\quad$ should accord with factors cited by practitioners as important.

With regard to the factors in Table 4, empirical work on Schumpeter's theory mainly links firms with investment in innovation rather than its fruits. Even at this level Conner (1991: 128) says that "empirical investigations are beset by measurement and data problems and offer inconclusive results". Links are not seen as being strong, although this is an empirical question in the context, seeing that innovation proxies all factors.

With, at best, indirect links to the make-buy decision and little empirical support, we exclude this theory.

\section{- Resource-based theory}

For our purpose, this theory may also be called capabilities or competence theory. Resource-based theory sees firms as having costly-to-copy attributes from which managers extract economic gain. Managers may choose only to make costly-to-copy attributes focusing on core competencies. Resource-based theory has promise as, coming from Penrose's (1959) approach, it focuses on managerial decisions. These managers may be similar to the managers that we envisage. However, there may be questions whether this theory enlarges, or conflicts with, neo-classical theory ${ }^{5}$. 


\section{- must allow the question of make or buy to be asked and answered}

As each firm is a unique set of resources and relationships, the choice of making or buying is a large issue in resource-based theory. An important point is that of distinguishing core competencies.

\section{- must lead to patent factors, and}

Consider core and non-core competencies for making and buying. Drtina (1994) advocates outsourcing (buying) non-essential services when this offers advantages in respect of cost, flexibility, and access to the latest technology. Quinn and Hilmer (1994) agree, adding that the manager should "concentrate the firm's own resources on a set of 'core competencies' where it can achieve definable pre-eminence and provide unique value for customers...Strategically outsource other activities - including many traditionally considered integral to any company - for which the firm has neither a critical strategic need, nor special capabilities." This stance of outsourcing non-core activities is however not universally advocated. Chesborough and Teece (1996: 73) would restrict buying to specific types of innovation. Prahalad and Hamel caution on outsourcing as follows: "Outsourcing can provide a shortcut to a more competitive product, but it typically contributes little to building the peopleembodied skills that are needed to sustain product leadership" (1990: 84). They neither advocate nor reject buying in the case of non-core activities ${ }^{6}$ So the theory is

clear on make for core resources, but not clear on make-buy of non-core resources.

The theory needs empirical testing on certain points. Preliminary attempts to test resource-based theory empirically (e.g. Maijoor \& Van Witteloostjuin, 1996) do not concern the factors essential to our purpose. Argyres (1996: 129) explains the state of the theory, saying "unlike transaction cost logic, the capabilities approach as yet cannot generate empirical predictions, only ex post explanations." As the theory is as yet undeveloped in its treatment of non-core activities, its recommendations are not yet clear.

\section{- should accord with factors cited by practitioners as important}

Resource-based theory specifically has merit in that practitioners base the makebuy decision heavily on inadequate resources such as lack of skill and facilities. In addition, practitioners specifically use the theory's terms core, non-core and focus. This makes resource-based theory attractive.

Resource-based theory has much to offer. It includes factors that some practitioners cite as important, and clearly favours making where core competency exists. Yet there may be difficulties with the theory for the makebuy decision. Questions are raised whether resource-based theory is consistent 
with the emphasis on cost and volume in the neo-classical approach, and how to deal with non-core resources. So, in spite of factors from this approach being cited in Table 4, this approach is not used. However, it is a strong contender and it is worth remembering that the manager may prefer to make core parts and processes.

\section{- Coase-Williamson or Transaction Cost Economics (TCE)}

The Coase-Williamson approach, also called transaction costs economics, extends neo-classical analysis of firms making, to avoid costs of buying in markets. (The terminology used is obscure but preserved in the explanation that follows.)

must allow the question of make or buy to be asked and answered, Making and buying are examples of transacting. The approach sees firms making to avoid costs of buying in markets. Costs include, but go beyond, those found in the neo-classical approach. For example, they include deception. Williamson's costs include those arising from a person's "bounded rationality" with simultaneous "opportunism". "Bounded rationality" means taking judicious decisions (as is done in neo-classical economics), but with limited personal capacity to process information. An "opportunistic" person is self-seeking with guile. Such a person can mislead with information that is difficult to ascertain. The cost of dealing with such people cannot be easily determined, and there may be differences between prior expectations and actual behaviour. Even with credible commitments from, and frequent transactions with, such a person, it may be cheaper to employ than to buy from the person. Employment means making while buying means market transactions.

- must lead to patent factors, and

In deciding what to make and what to buy, Williamson says that frequency of transactions, investment characteristics and uncertainty are important. While uncertainty and frequency of transactions have standard meanings, investment characteristics need some elaboration. Investment characteristics are specific stakes of parties to a transaction. Put another way, investment characteristics measure the amount put into a particular deal. Williamson gives four investment characteristics, also called specificities. These are site-specific, physical asset-specific, human asset-specific and dedicated assets. 
- Site-specific is where location, once undertaken, is costly to change, for example locating a coal-fired electricity generating station near a particular coal-mine.

- Physical asset-specific is where special equipment has to be made for the process alone.

- Human asset-specific is where people have special skills not easily transferred.

- Dedicated asset is where a facility is made in response to a specific customer, for example, a supplier building a plant to smelt ore for an aluminium buyer.

For the situation given in section 2, the manager is not concerned with decisions that occur infrequently and do not allow reviewing the decision after locating the plant, so we eliminate site-specificity and dedicated assets.

The manager, in the situation using the Coase-Williamson approach, would have the following as important factors:

from neo-classical analysis:

- Costs,

- Volume effects, and

from TCE:

- Physical asset-specificity,

- Human asset-specificity, and

- Uncertainty

This approach advocates that the manager, undertaking frequent transactions, should follow the prescriptions of neo-classical theory and:

- buy with ordinary contracts when investment characteristics are nonspecific,

- $\quad$ make when investment characteristics are unique and build relationships ${ }^{7}$, and

- make when there are high levels of uncertainty.

- should accord with factors cited by practitioners as important Consider the factors relative to those in Table 4. Cost and volume effects are repeated. Resource skills and facilities are found in human and physical asset- specificities, respectively. Uncertainty may be reflected in reliability. Thus factors outlined mirror the practitioners' most highly ranked reasons for the make-buy decision. 
Given both the evidence from practitioners and the theories outlined above, the Coase-Williamson theory (Williamson, 1985) or Transactions Cost Economics (TCE) is currently the most attractive make-buy theory for the given situation ${ }^{8}$.

\section{CONCLUSION}

We advocate that the manger, in the situation described, uses the CoaseWilliamson theory. It allows the make-buy question to be asked and answered, leads to patent factors and accords with the factors cited by practitioners as important. Augmenting neo-classical economics, it forms a secure basis for the make-buy decision described. In addition, the manager may wish to enhance this by the resource-based theory prescription to make parts and processes at the core of the firm and monitor further developments in this area.

\section{APPENDIX 1}

\section{Practitioners' Views of Making and Buying}

Some published literature shows that practitioners advocate either making or buying. Current articles were selected to cover both service and product elements. These studies are summarised in Table Al, showing sources and reasons for making or buying. As far as possible, authors' original terms have been retained. In Table A1, columns are arranged as follows: the sources of the study comprising the names of the author(s), task considered for making and/or buying, and where the study is undertaken, are in the first column. The second column has factors important in coming to the decision whether to make or buy. Words are interspersed with letters from (A) to (I) corresponding to factors. These are transferred to the last nine columns A to I. The rows in Table Al are divided into factors which managers control, called endogenous, and factors where managerial control is tenuous (e.g. legislation), called exogenous. Total frequencies for each column A to I give an idea of the importance of a factor in this sample for the make-buy decision. By total frequencies, practitioners cite cost, volume, speed and then competence as important in make-buy decisions. 
Table A1 Practitioners' Factors for Making and Buying

\begin{tabular}{|c|c|c|c|c|c|c|c|c|c|c|}
\hline Sources of study & Reasons given for making or buying & & & & & & & & & \\
\hline Author; Task (group); Area & Buy-; Make-; Make or Buy Decision Factors & Far & tor & (se & ke & $\mathbf{b}$ & ow & & & \\
\hline ENDOGENOUS SERVICE & & $\mathbf{A}$ & B & $\mathrm{C}$ & $\mathrm{D}$ & $\mathrm{E}$ & $\mathbf{F}$ & $\mathbf{G}$ & $\mathbf{H}$ & I \\
\hline $\begin{array}{l}\text { Smith (1996: } 40) ; \\
\text { developing integrated } \\
\text { financial accounting } \\
\text { systems; Canada }\end{array}$ & $\begin{array}{l}\text { Buy- cost (A) effective and rapidly } \\
\text { implemented (D) } \\
\text { Make- The company has the more } \\
\text { understanding of problems- inefficiencies, } \\
\text { inadequacies and loss of competitive edge (B) }\end{array}$ & 1 & 1 & & 1 & & & & & \\
\hline $\begin{array}{l}\text { Anthes (1997: } 75 \text { ); internet } \\
\text { functions; US companies }\end{array}$ & $\begin{array}{l}\text { Buy- a fast start-up is important (D), skills are } \\
\text { lacking internally (F), an outsourcer has better } \\
\text { security arrangements (G), and high reliability } \\
\text { and round-the-clock coverage is needed (H) } \\
\text { (that cannot be provided in-house). } \\
\text { Make- services are of strategic importance (E) } \\
\text { and the company demands maximum control, } \\
\text { services are ill-defined (B), the company } \\
\text { demands, and can provide in-house, rapid } \\
\text { change to design and content (D), and the } \\
\text { company can do it more cost-effectively (A). }\end{array}$ & 1 & 1 & & 1 & 1 & 1 & 1 & 1 & \\
\hline $\begin{array}{l}\text { Malloy (1997: 88); IS } \\
\text { managers; }\end{array}$ & $\begin{array}{l}\text { Make- Security fears (G), Equipment and } \\
\text { training investments and lack of trust (G) in } \\
\text { keep IS holding on to remote access. (Other } \\
\text { deterrents include investment already in } \\
\text { equipment and employee training). }\end{array}$ & & & & & & & 1 & & \\
\hline
\end{tabular}


Table A1 continued

Sources of study

Author; Task (group); Area

Reasons given for making or buying

Kiely, (1997: 11-12); business processes that IT supports, e.g. billing and logistics management;

Buy-; Make-; Make or Buy Decision Factors

Buy- escalating number of service providers allows buyers to bargain on price (A), and many service providers are able to handle bigger, more complex work (C). ENDOGENOUS PRODUCT

"Make or Buy? Research Buy- Domestic suppliers cannot meet all the Findings", (1996: 28); competitive needs of consumers (volume) (C) clothing industry; UK

Johnson and Leenders, (1997: 20-6); ferrous scrap

Gain (1997: S10-S16);

Decision to Make or Buy-Volume is dominant pharmaceutical (C)

pesticide; US

Moore (1996: 28-31); Decision to Make or Buy. Buy special-purpose making bar code labels; US companies

Haner (1997: 80, 78); appliance industry product development; US.

labels Special services, volumes (C) are low and/or orders intermittent, cost (A), and performance (B).

Buy- Expanding capacity in the corporate environment such as a lack of specialised experience ( $F)$, the inherent nature of the corporate structure and culture (I)

Make- Firm is more competitive. Managers focus their firm's resources on core competencies $(E)$ and can save costs (A), time (D), and other resources (F)

\section{Factors (see key below)}

1
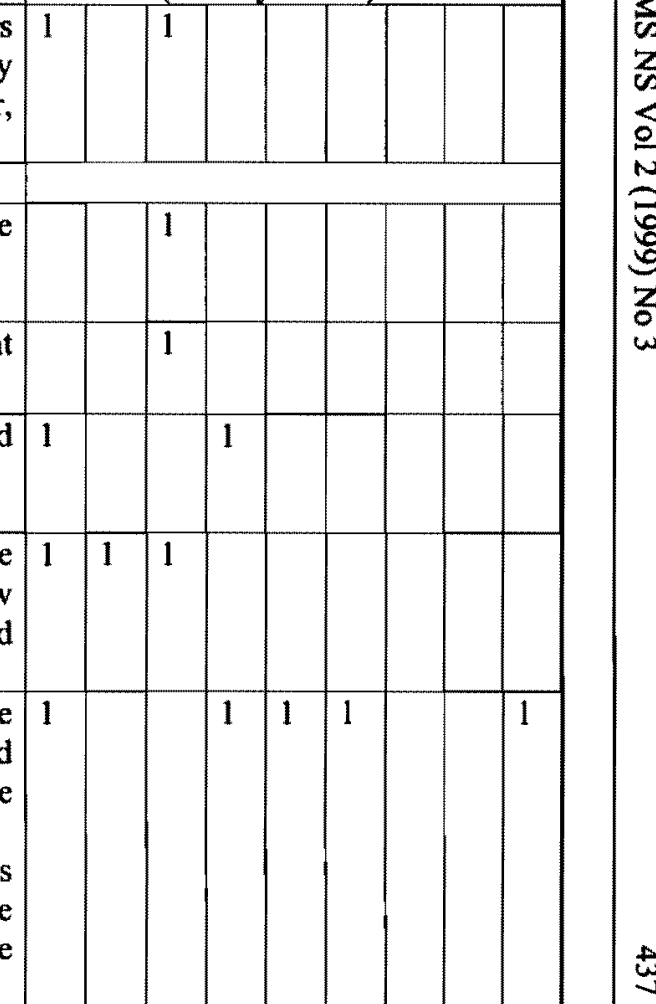
Table A1 continued

\begin{tabular}{|c|c|c|c|c|c|c|c|c|c|c|}
\hline Sources of study & Reasons given for making or buying & & & & & & & & & \\
\hline Author; Task (group); Area & Buy-; Make-; Make or Buy Decision Factors & \multicolumn{9}{|c|}{ Factors (see key below) } \\
\hline \multicolumn{11}{|l|}{ EXOGENOUS } \\
\hline $\begin{array}{l}\text { Johnson and Leenders } \\
\text { (1997; 20-26); ferrous } \\
\text { scrap; US plants }\end{array}$ & $\begin{array}{l}\text { Decision to Make or Buy- Government } \\
\text { regulations, competitive pressures, and public } \\
\text { opinion (B) }\end{array}$ & & 1 & & & & & & & \\
\hline $\begin{array}{l}\text { Ferguson } \quad(1996: 34-36) ; \\
\text { electrical } \\
\text { US. }\end{array}$ & $\begin{array}{l}\text { Decision to Make or Buy- Changing from } \\
\text { regulated to unregulated (B) }\end{array}$ & & 1 & & & & & & & \\
\hline \multicolumn{11}{|c|}{ EXOGENOUS \& ENDOGENOUS } \\
\hline $\begin{array}{l}\text { Kurokawa (1997: 124- } \\
\text { 134); R\&D; Japan and US } \\
\text { high tech industries }\end{array}$ & $\begin{array}{l}\text { Decision to Make or Buy- number of rivals } \\
\text { expected to develop a similar product (B) and } \\
\text { needed technology is less related to a firm's core } \\
\text { technology (endogenous) (E) }\end{array}$ & & 1 & & & 1 & & & & \\
\hline Total Frequency & & 6 & 6 & 4 & 4 & 3 & 3 & 2 & 1 & 1 \\
\hline
\end{tabular}

Column key - Factors
(A) is Cost including price
(B) is other factors not specified elsewhere
(C) is Volume including demand
(D) is Speed
(F) is Inadequate resources
(G) is Trust, security and theft
(H) is Reliability
(I) is Corporate structure and culture
(E) is Competence, strategy or strategic 


\section{ENDNOTES}

1 It may ensure that the part or process is not stolen!

2 This is part of the Industrial Make vs Buy Decisions (Research Grant number GR/L63013) being conducted at Cambridge University.

3 There are alternate classifications, e.g. Teece et al. (1997: 527)

4 The dynamic capabilities model by Teece et al. (1997) has not had time to be empirically tested and is excluded.

5 Penrose's theory is a growth dynamic theory whilst neo-classical theory is a static profit maximisation theory.

6 Venkatesan's (1992) well-cited case of whether to make or not, maintains the status quo.

7 Williamson advocates forming alliances when investment characteristics are at a mixed stage.

8 TCE or the Coase-Williamson theory, has roots in neo-classical economics therefore, no clash is expected when including neo-classical theory factors.

\section{REFERENCES}

1 ANTHES, G.H. (1997). "Ousourcing Pros and Cons". Computerworld, 31(14): 75 .

2 CHESBOROUGH, H.W. and TEECE, D.J. (1996) "When is Virtual Virtuous, Organizing for Innovation". Harvard Business Review, 74(1): 65-73.

3 CONNER, K.R., (1991) "A Historical Comparison of Resource-based Theory and the Five Schools of Thought within Industrial Organization Economics: Do we Have a New Theory of the Firm?" Journal of Management, 17(1): 121-54.

4 DRTINA, P.E., (1994) "The Outsourcing Decision". Management Accounting (US), 75(9): 52-62.

5 FERGUSSON J.S., (1996) "Transmission or Distribution? Reengineering Cost-of-service Studies for the Emerging Competitive Market", Public Utilities Fortnightly, 134(3).

6 GAIN, B., (1997) "Custom Manufacturing Takes Off", Chemical Week, Custom Manufacturing Profiles Supplement, May 14: S10-S16.

7 HANER, R. (1997) "Smart Outsourcing: Product Development". Appliance Manufacturer, 45(4): 80 \& 78 .

8 HAY, D.A. and MORRIS, D.K. (1991) Industrial Economics and Organization - Theory and Evidence, Oxford University Press, Oxford. 
9 JOHNSON, P.F. and LEENDERS, M.R. (1997) "Make-or-buy Alternatives in Plant Disposition Strategies", International Journal of Purchasing and Materials Management, Vol. 33: 20-6.

10 KIELY, T. (1997) "Business Processes: Consider Outsourcing", Harvard Business Review, Vol. 75(3): 11-12.

11 KUROKAWA, S. (1997) "Make-or-Buy Decisions in R\&D: Small Technology Based Firms in the United States and Japan", IEEE Transactions On Engineering Management 44 (2)": 124-34.

12 LOASBY, B.S., (1976) Choice, Complexity and Ignorance, C.U.P., Cambridge.

13 MACHLUP, F. (1967) "Theories of the Firm: Marginalist, Behavioral, Managerial", The American Economic Review, 57(1): 1-33.

14 MAIJOOR, S. and VAN WITTELOOSTJUIN, A. (1996) "An Empirical Test of the Resource Based Theory: Strategic Regulation in the Dutch Audit Industry" Strategic Management Journal, 17(7): 549-69.

15 "Make or Buy? Research Findings" (1996) Logistics Focus, 4(2).

16 MALLOY, A. (1997) "The Outsourcing Option", Computerworld, 31(8): 88.

17 MCGAHAN, A.M. \& PORTER, M.E. (1997) "How Much Does Industry Matter Really?", Strategic Management Journal, 18(Special Issue): 15-30.

18 MOORE, B. (1996) "Bar Code Labels: Make or Buy?", Automatic I.D. News, 12(3): 28-31.

19 NEWELL, A. (1996). "Selected Environmental Uncertainties, Manufacturing Flexibility and Subcontracting" $M S c(E n g)$ Research Report, Faculty of Engineering, University of the Witwatersrand, Johannesburg, Unpublished.

20 PELTZMAN, S. (1991) "The Handbook of Industrial Organization: A Review Article", Journal of Political Economy, 99(1): 201-17.

21 PENROSE, E. (1959) The Theory of the Growth of the Firm, O.U.P., Oxford.

22 PRAHALAD, C.K. \& HAMEL, G. (1990) "The Core Competence of the Corporation". Harvard Business Review, 68(3): 79-91.

23 QUINN, J.B. \& HILMER, F.G. (1994) "Strategic Outsourcing", Sloan Management Review, 35(4): 43-55.

24 Smith, G. (1996) "The Make-or-Buy Dilemma", Computing Canada 22(17): 40 .

25 TEECE, D.J., PISANO, G. and SHUEN, A. (1997) "Dynamic Capabilities and Strategic Management", Strategic Management Journal, 18(7): 509-53

26 VENKATESAN, R. (1992) "Strategic Sourcing - To Make or Not to Make", Harvard Business Review, 70(6): 98-107. 
27 WILLIAMSON, O.E. (1979) "Transaction Cost Economics: The Governance of Contractual Relations", Journal of Law and Economics, 22(2): 233-61.

28 WILLIAMSON, O.E. (1985) The Economic Institutions of Capitalism, The Free Press, New York. 